\title{
Market size and foreign direct investment in sub-Saharan Africa: the role of education
}

\author{
JEMILUYI Olufunmilayo Olayemi; DADA James Temitope \\ Department of Economics, Obafemi Awolowo University, Ile-Ife, Nigeria \\ e-mail correspondence: olayemiolufunmilayo@gmail.com
}

\begin{abstract}
This study examines the role of education in the nexus between foreign direct investment (FDI) and market size in sub-Saharan African countries from 2005 to 2015 using a panel of 30 countries. Market size is proxy by gross domestic product and population while two variables are used to measure education; primary school enrolment and secondary school enrolment. Difference Generalised Method of Moments (GMM) is used as the estimation technique. The result shows that education and market size have positive and significant effect on foreign direct investment. The interactive effect of market size (population and gross domestic product) and education (both primary and secondary school enrolment) has positive effect on foreign direct investment. The study concludes that policy maker in the region should focus more on the quality of education rather than quantity of education.
\end{abstract}

Keyword: Foreign Direct Investment, Market size, Education, Population, Gross Domestic Product

JEL classification: E22, F41, F43, O11

\section{INTRODUCTION}

Although foreign direct investment (hereafter FDI) has been argued as an important source of shocks emanating from the international markets (Xing and Pradhananga, 2013; Caballero, 2002), its immense contribution to the growth and development of the less developed economies such as Asia, Africa, Latin America cannot be over emphasized. In addition to promoting competition, increasing capital inflow, creating both direct and indirect employment, FDI has also played crucial roles in technological spillover, crowding in additional domestic investment, improving access to international market and reinforcing economic interdependence (Moura and Forte, 2010; Alfaro et al., 2004). Thus, the discussion of the growth-enhancing effect and determinants of FDI inflow have been intensively researched over the last four decades.

With strong evidence in favour of the growth-enhancing effect of FDI through increased investment, employment and productivity (Desbordes and Wei, 2017; Alfaro et al, 2004), attracting FDI has remained a top agenda in developmental plans of most developing economies including sub Saharan African countries. However, data on FDI flows in Africa has revealed that Africa compares less to other developing continents of Asia and Latin America in terms of size and sectorial composition. For instance, the total inflow of FDI into Africa in 2014, 2015 and 2016 was \$71 billion, \$61 billion and $\$ 9$ billion respectively compared with $\$ 460$ billion, $\$ 524$ billion and $\$ 443$ billion for 
Asia in the same period. Total FDI into India (in Latin America) in the same period was more than half of total inflow into the whole continent of Africa in each period (\$34.57billion, \$44.01billion and \$44.46billion respectively) (UNCTAD, 2017). Also, while the sectorial composition of FDI in Latin America and Asia reveal concentration in the manufacturing and service sectors, FDI in Africa has been largest for the extractive sector with the consequential implication for natural resource depletion and environmental degradation.

Regardless of the geographic locus, a chunk of the large body of empirical evidence on factors determining the attraction of FDI to the host countries has argued in favour of market size (Kohler, 2013; Ho et al., 2013). This conclusion has been hinged on market size-related benefits such as economies of scale exploitation, production factor specialization, high demand and efficient utilization of resources (PetrovićRanđelović et al. 2017; Chakrabarti, 2001; Balassa, 1966). The dominant role of market size (measured by level of economic development or population size) in FDI attraction is evidenced in the high level of FDI inflow into the world's largest economies. In 2010, the world's largest ten economies account for the 47\% of all FDI inflow. In 2015, US, the world largest economy accounted for the largest inflow of FDI receiving \$476. 69 billion, followed by China, the most populous which received $\$ 242.49$ billion (UNCTAD, 2017). Multinational companies (MNCs), owners of FDI are likely to move to countries with larger and expanding markets and greater purchasing power, where there are potentials to receive a higher return on their investment and by implication earn higher profit from their investment.

Like in most economies of the world, empirical investigations of determinants of FDI in SSA has also established a positive link between market size and FDI. However, the expected large market from a high population has been argued to be non-sacrosanct as the high purchasing power effect implied by the supposed large market is not inevitable (Kohler, 2013; Asiedu, 2002). Asiedu (2002) argues that market size is not a determining factor for inflow of FDI in developing economies due to low income. Put differently, large market size is not sufficient to attract foreign investment in developing economies, high level of income is also essential. Even though a large market size is essential to attract FDI, what is more important is the purchasing power commanded by the large population. If a larger share of the population is engaged in subsistence agriculture and other low paying jobs as the case in most sub-Saharan Africa countries, high demand-effect due to large market size may not arise.

Human capital, in particular, education is correlated to income (Glewwe et al., 2014; Jamison et al. 2006; Barro, 1991). The income-effect of education has been extensively demonstrated in the literature. Based on empirical findings, education potentially enhance individual earning capacity by increasing productive skills. On the aggregate, education has been found to play a significant role in the productivity of an economy, and hence determine the growth of aggregate income. Therefore, an economy with large number of skilled and educated population is likely to have higher market size compared with those characterized by pool of unskilled/uneducated population. While some developing countries of Asia have come out of poverty using effective educational polices, many developing countries of Africa have remained stuck in the low skill-low income trap (UNCTAD, 2006). High-income consumer market has higher purchasing power and hence greater demand for produced goods and services.

In addition to the income-effect, education also has important implications for efficiency-seeking motive of FDI. Multinational companies seek to invest in countries with large number of educated labour force. Education is an important factor in boosting 
labour efficiency and productivity. Educated and skilled labour force are able to conduct research and development (R\&D) and help in diffusing technology. With large pool of educated labour force, wages for domestic skilled labour becomes relatively cheaper to wages of expatriate (Aziz and Makkawi, 2012). Many emerging economies of Asia have been able to attract huge FDI inflow compared to their market size, reflecting their relative success in attracting FDI for efficiency reasons rather than large market size. Large scale presence of information and communication technology MNCs in India, South Korea and China signifies a major evidence of positive impact of educated labour force in FDI attraction.

Although, large body of evidence on the ongoing debate on FDI determinants in Africa has regards the role of market size, but the mediating role of education in the FDI-market size nexus has not been addressed in the existing literature. This missing link may explain the difference in the level of FDI inflow among countries or region with similar market size or why countries or region with larger market size have attracted lower FDI relative to country with lower market size. This study therefore contributes to the existing literature by analyzing the mediating role of education in the FDI-market size nexus.

The empirical investigation of the determinants of FDI has remained an ongoing research with a large body of evidence on both time series and panel analyses. For SSA in particular, there exist a plethora of studies examining the nexus between FDI and various identified factors, both for the region as well as country specific. A number of factors important for the attraction of FDI to the host country have been identified in the literature. For instance, extant literature have shown that trade openness (Sakyi, Commodore and Pokou, 2015), infrastructural development (Bakar, Che Mat and Harun, 2012), institutional framework (Daude and Stein, 2014; Alguacil, Cuadros and Orts, 2011), natural resources endowment (Kudaisi, 2014), quality of human capital, financial development (Nwosa and Emma-Ebere, 2017; Desbordes and Wei, 2017) and macroeconomic stability (Shah, 2016; Alguacil, Cuadros and Orts, 2011) play important roles in the location choice decision of foreign investors.

Since the seminal paper of Balassa (1966), several authors have likewise contributed to the increasing literature on the nexus between market size and FDI. The early contributions focus on the US and European economies, Bandar and White (1968), Lunn (1980), Kravis and Lipsey (1982) and Nigh (1985) finds that market constitutes an important factor in determining the inflow of FDI into host country. Jaumotte (2004) also concludes that market size advantage of regional trade agreement (RTA) in developing regions is a strong determinant of FDI inflow into countries participating in the RTA.

Dermirhan and Masca (2008) argues that the effect of market size on FDI depend largely on the adopted measure of market size. The study finds no empirical evidence of relationship between FDI inflow and market size proxy by absolute GDP or GDP per capita. It however establishes a significant effect of growth of per capita real GDP on FDI inflow. Mughal and Akram (2009) examines the impact of market size on the location choice decision of MNCs and finds that while there is no evidence of influence of market size on FDI inflow in the short run, market size do play a significant role in attracting FDI in the long run.

In a more recent study, Hoang and Bui (2015) finds that market size is positively related to FDI flow into ASEAN countries. Anyanwu and Yameogo (2015) finds a similar result in an empirical investigation of the determinants of FDI into West African countries. In an empirical analysis of Malaysia outward FDI, Goh and Wang (2010) 
confirms that host market size is crucial to Malaysia outflow of FDI. Similarly, Petrovic-Ranđelovic et al. (2017) examines the effect of market size, market growth, trade openness and population on FDI inflow in the Western Balkan countries. The empirical finding shows among other things that market size plays a significant role in influencing FDI location choice in Balkan countries. The above studies ignored to look at the intermediate role of education in the FDI- market size nexus. This creates an empirical gap that needs further studies hence, this study. The remainder of this paper is organized as follows: section 2 contains methodology, section 3 presents empirical results while section 4 focuses on conclusion and section 5 centres on policy recommendation.

\section{METHODOLOGY}

\section{Conceptualisation}

The theoretical framework of this study rest on the "Eclective Paradigm" of Dunning (1977, 1993), which posit that multinational companies invest in another country because of three advantages namely: Ownership (O), Location (L) and Internalisation (I). This paradigm has been popularly called the OLI framework. Similarly, based on the aforementioned advantages, Dunning (1993) highlighted four major reasons for FDI; resource seeking (such as infrastructural facilities, raw materials, labour force, etc.), market seeking (e.g. population, income, etc.), efficiency seeking (such as development of human capital), and strategic asset seeking (such as R\&D, technology, innovation, etc.). Since it has been established in the literature that market size is one of the major determinant of FDI, human development indicators such as education which is one of the driver of the quality of human capital (Beaker, 1995; Hanushek and Denis, 2000) are linked with FDI. For instant, MNCs may be interested in a particular country due to the quality and quantity of expertise of labour force, as adequately trained domestic labour force reduced offshoring of skilled labour force which is common among MNCs. Furthermore, a skilled manpower receives higher wages, which translate to higher income for the country. From the above, the study proceeds to specify the baseline empirical model which captures the hypothesized relationship. The model is stated as

$$
F d i_{i t}=f\left(M r k_{i t}, E d u_{i t}, Z_{i t}\right)
$$

where Fdi is foreign direct investment, Mrk is market size, Edu is education and Z is other variables affecting foreign direct investment. In order to capture the intervening role of education in FDI-Market size nexus, equation 1 is stated as

$$
F d i_{i, t}=f\left(M r k_{i, t}, E d u_{i, t}, M r k_{i, t} * E d u_{i, t}, Z_{i, t}\right)
$$

Specifying equation 2 in specific form becomes

$$
F d i_{i, t}=\alpha+\beta M r k_{i, t}+\chi E d u_{i, t}+\phi M r k_{i, t} E d u_{i, t}+\varphi Z_{i, t}+\gamma F d i_{i, t-1}+\delta_{t}+v_{i}+u_{i t}
$$

Where $v_{i}$ is country specific effect, $\delta_{t}$ is the time effect and $\mu_{i t}$ is the error term.

\section{Measurement and description of variables}

Foreign Direct Investment (FDI): Foreign direct investment refers to direct investment equity flows in an economy. It is the sum of equity capital, reinvestment of earnings, and other capital. Net inflow of FDI as a percentage of GDP is used to measure FDI 
Market Size: Two variables are used to measure market size: population and gross domestic (GDP) product. The larger the population and domestic income implies a greater market for MNCs. Population growth rate is used to proxy population while growth rate of GDP is used to measure gross domestic product.

Education: Education is proxy using two indicators namely primary school enrolment and secondary school enrolment.

Other control variables included in the model are: trade openness and inflation rate. Trade openness measure the relationship of the country with the rest of the world in term of trade, while inflation rate measures the macroeconomic stability or instability in an economy.

The data set comprises of 30 countries in sub-Saharan Africa from 2005 to 2015 (see Appendix A for list of countries selected). The data were collected from World Bank Development Indicators (WDI) of the Word Bank 2016 Edition.

\section{Estimation technique}

Difference Generalised Method of Moments (GMM) is used as the estimation technique. As noted by Bond et. al. (2001) and Wooldridge (2001), GMM technique has four major strengths. Firstly, it produces estimates not bias by omitted variables, secondly, it produces estimates which are consistence even in the presence of measurement error. Thirdly, it is robust in solving endogenity problem and nonnormality in the data. Lastly, it exploits an assumption about the initial conditions to obtain moment conditions that remain informative even for persistent series. Estimation of GMM is based on the assumption that there are a set of $\mathrm{L}$ moment conditions that the $\mathrm{K}$ dimensional parameters of interest should satisfy. When there are more moment conditions than parameters, the system of equations may not provide an exact solution and thus it is said to be over-identified. For GMM estimators to be identified, there must be at least as many instruments as there are parameters in the model. When there are more instruments than the parameters, J-statistic will be greater than zero, but when the number of instruments is the same as the number of parameters, J- statistic is zero. In order to obtain over- identifying restrictions, the past values of the explanatory variables as well as the dependent variables can be added as moment conditions as long as they are uncorrelated with the error term (Wooldridge, 2001). This study employs the lag values of dependent as instrument variable. As a robustness check, Random effect model was used to confirm the GMM result.

\section{EMPIRICAL RESULT}

Table 1 shows the result of the effect of market size and education on foreign direct investment inflow into sub-Saharan African countries. Two variables were used as proxy for market size namely gross domestic product and population. Also, two variables were used to measure education: primary school enrolment and secondary school enrolment. The result confirms that market size is one of the major determinant in SSA, since both proxy of market size (gross domestic product and population) have positive and significant effect on foreign direct inflow into SSA. Comparing the effect of gross domestic product and population on FDI, the result reveals that population has more effect on FDI than gross domestic product. It has also been established in the literature that large population drives FDI since it serves as a potential market for multinational companies, and their interest is where they can get maximum return on their investment. This confirms the market seeking hypothesis of Dunning (1993) 
Table 1 Foreign direct investment, Market size and Education

\begin{tabular}{|c|c|c|c|c|c|c|c|c|}
\hline \multirow[b]{2}{*}{ FDI(-1) } & \multicolumn{4}{|c|}{ GMM } & \multicolumn{4}{|c|}{ Random Effect Model (REM) } \\
\hline & $\begin{array}{r}0.048 \\
{[0.01]} \\
(0.000)^{* * *}\end{array}$ & $\begin{array}{r}0.064 \\
{[0.115]} \\
(0.000)^{* * *}\end{array}$ & $\begin{array}{r}0.018 \\
{[0.012]} \\
(0.131) \\
\end{array}$ & $\begin{array}{r}0.099 \\
{[0.005]} \\
(0.000)^{* * *}\end{array}$ & & & & \\
\hline $\mathbf{C}$ & & & & & $\begin{array}{r}5.094 \\
{[1.935]} \\
(0.009)^{* * *} \\
\end{array}$ & $\begin{array}{r}5.934 \\
{[2.330]} \\
(0.012)^{* *} \\
\end{array}$ & $\begin{array}{r}5.362 \\
{[1.716]} \\
(0.002)^{* * *} \\
\end{array}$ & $\begin{array}{r}9.154 \\
{[2.115]} \\
(0.000)^{* * *} \\
\end{array}$ \\
\hline GDP & $\begin{array}{r}2.365 \\
{[0.356]} \\
(0.000)^{* * *}\end{array}$ & $\begin{array}{r}0.643 \\
{[0.840]} \\
(0.445)\end{array}$ & & & $\begin{array}{r}1.316 \\
{[0.143]} \\
(0.000)^{* * *}\end{array}$ & $\begin{array}{r}1.202 \\
{[24.831]} \\
(0.961)\end{array}$ & & \\
\hline Population & - & & $\begin{array}{r}25.327 \\
{[1.888]} \\
(0.000)^{* * *} \\
\end{array}$ & $\begin{array}{r}4.399 \\
{[1.258]} \\
(0.001)^{* * *} \\
\end{array}$ & & & $\begin{array}{r}1.578 \\
{[9.912]} \\
(0.874) \\
\end{array}$ & $\begin{array}{r}15.578 \\
{[5.583]} \\
(0.006)^{*}\end{array}$ \\
\hline Primary education & $\begin{array}{r}6.410 \\
{[0.950]} \\
(0.000)^{* * *} \\
\end{array}$ & & $\begin{array}{r}25.788 \\
{[1.151]} \\
(0.000)^{* * *} \\
\end{array}$ & & $\begin{array}{r}2.863 \\
2.406 \\
(0.734)\end{array}$ & & $\begin{array}{r}0.748 \\
{[3.148]} \\
(0.812)\end{array}$ & \\
\hline $\begin{array}{l}\text { Secondary } \\
\text { education }\end{array}$ & - & $\begin{array}{r}3.679 \\
{[1.252]} \\
(0.004)^{* *}\end{array}$ & & $\begin{array}{r}20.686 \\
{[0.513]} \\
(0.000)^{* * *}\end{array}$ & & $\begin{array}{r}24.381 \\
{[11.053]} \\
(0.0257)^{* *}\end{array}$ & & $\begin{array}{r}6.853 \\
{[2.041]} \\
(0.001)^{* * *}\end{array}$ \\
\hline $\begin{array}{l}\text { GDP*Primary } \\
\text { education }\end{array}$ & $\begin{array}{r}52.157 \\
{[10.199]} \\
(0.000)^{* * *} \\
\end{array}$ & & & & $\begin{array}{r}47.608 \\
{[17.922]} \\
(0.0464)^{* *} \\
\end{array}$ & & & \\
\hline $\begin{array}{l}\text { GDP*Secondary } \\
\text { education }\end{array}$ & - & $\begin{array}{r}16.192 \\
{[13.011]} \\
(0.215) \\
\end{array}$ & & & & $\begin{array}{r}16.078 \\
{[26.717]} \\
(0.0032)^{* *} \\
\end{array}$ & & \\
\hline $\begin{array}{l}\text { Population* } \\
\text { Primary education }\end{array}$ & & & $\begin{array}{r}79.257 \\
{[3.880]} \\
(0.000)^{* * *} \\
\end{array}$ & & & & $\begin{array}{r}4.052 \\
{[15.399]} \\
(0.972) \\
\end{array}$ & \\
\hline $\begin{array}{l}\text { Population* } \\
\text { Secondary school }\end{array}$ & & & & $\begin{array}{r}65.522 \\
{[1.803]} \\
(0.000)^{* * *}\end{array}$ & & & & $\begin{array}{r}20.836 \\
{[7.518]} \\
(0.006)^{* * *}\end{array}$ \\
\hline Trade openness & $\begin{array}{r}0.001 \\
{[0.002]} \\
(0.170) \\
\end{array}$ & $\begin{array}{r}0.0002 \\
{[0.004]} \\
(0.965) \\
\end{array}$ & $\begin{array}{r}0.0002 \\
{[0.0003]} \\
(0.465) \\
\end{array}$ & $\begin{array}{r}0.0003 \\
{[0.002]} \\
(0.000)^{* * *} \\
\end{array}$ & $\begin{array}{r}0.0001 \\
{[0.008]} \\
(0.087)^{*} \\
\end{array}$ & $\begin{array}{r}0.002 \\
{[0.0008]} \\
(0.058)^{*} \\
\end{array}$ & $\begin{array}{r}0.002 \\
{[0.0008]} \\
(0.072)^{*} \\
\end{array}$ & $\begin{array}{r}0.002 \\
{[0.0008]} \\
(0.015)^{* *} \\
\end{array}$ \\
\hline Inflation & $\begin{array}{r}-0.020 \\
{[0.003]} \\
(0.000)^{* * *} \\
\end{array}$ & $\begin{array}{r}-0.010 \\
{[0.009]} \\
(0.965) \\
\end{array}$ & $\begin{array}{l}-0.007 \\
{[0.011]} \\
(0.545) \\
\end{array}$ & $\begin{array}{r}-0.013 \\
{[0.004]} \\
(0.001)^{* * *} \\
\end{array}$ & $\begin{array}{l}-0.005 \\
{[0.017]} \\
(0.768) \\
\end{array}$ & $\begin{array}{l}-0.005 \\
{[0.017]} \\
(0.785) \\
\end{array}$ & $\begin{array}{r}0.004 \\
{[0.016]} \\
(0.823) \\
\end{array}$ & $\begin{array}{r}-0.007 \\
{[0.017]} \\
(0.687) \\
\end{array}$ \\
\hline $\begin{array}{l}\text { Number of } \\
\text { countries }\end{array}$ & 30 & 26 & 30 & 26 & 30 & 28 & 30 & 28 \\
\hline $\begin{array}{l}\text { Number of } \\
\text { instrument }\end{array}$ & 30 & 26 & 30 & 26 & & & & \\
\hline J-Statistic & 22.337 & 20.640 & 24.286 & 21.646 & & & & \\
\hline Sargan Test & $(0.366)$ & $(0.499)$ & $(0.478)$ & $(0.561)$ & & & & \\
\hline $\begin{array}{l}\text { Serial Correlation } \\
\text { Test }\end{array}$ & $(0.945)$ & $(0.738)$ & $(0.874)$ & $(0.916)$ & & & & \\
\hline Wald Test & $\begin{array}{r}26.153 \\
(0.000)^{* * *}\end{array}$ & $\begin{array}{r}1.549 \\
(0.215)\end{array}$ & $\begin{array}{r}41.725 \\
(0.000)^{* * * *}\end{array}$ & $\begin{array}{r}132 \\
(0.000)^{* * * *}\end{array}$ & $\begin{array}{r}11.338 \\
(0.000)^{* * * *}\end{array}$ & $\begin{array}{r}0.362 \\
(0.548)\end{array}$ & $\begin{array}{r}0.0012 \\
(0.972)\end{array}$ & $\begin{array}{r}7.680 \\
(0.006)^{* * *}\end{array}$ \\
\hline
\end{tabular}

Note:

1. Dependent variable is FDI

2. Standard errors are in parenthesis "[]"

3. Probability are in parenthesis "()"

4. *** significant at $1 \%$ level, $* * 5 \%$ level and $* 10 \%$ level

5. Wald test Null hypothesis: the interaction of market size and education is zero

6. No serial correlation and Sagan Test for Random Effect model 
Similarly, education is also one of the important human capital that a country cannot toil with. Increase in the school enrolment both at primary school and secondary school level drives FDI into the region. This also support the efficiency seeking argument of Dunning (1993). The effect of primary school education on FDI is much felt than secondary school education, which further reveals that governments/policy makers in SSA concentrated more on primary school education than secondary school education which is not adequate in guaranteeing a skilled economy.

The interaction of market size; population and gross domestic product with education at both primary and secondary education shows that it has positive effect on foreign direct investment. Interaction of primary school education with market size has more positive effect than the interaction of secondary school education with market size. Since the multinational companies need skilled manpower, this is one of the reasons multinational companies brings their expatriates while coming into the host country especially SSA. Furthermore, it could be the reason why the region has not attracted enough FDI in recent times. Multinational companies have shifted towards relatively skill-intensive production and service and less toward primary and resourcebased manufacturing. For countries seeking to attract higher value-added MNCs, it is necessary to upgrade human capital especially education above the basic schooling level (Majeed and Ahmad, 2008).

Other control variables included shows different effects on foreign direct investment. Trade openness has positive and significant effect on FDI inflow into the region. The more trade is liberalised in the region, the more the benefits that accrued to SSA countries. Inflation rate which measure the degree of economic stability has negative effect on inflow of FDI into the region. Stability of the macroeconomic environment is very importance for SSA countries to attract FDI to its fullest potentials

Applying random effect technique as a robustness check on the estimates of GMM, the result further buttress the results obtained from GMM estimates except that majority of the variables were not stationary.

Using Wald statistic to determine the significant of the interaction of market size and education on FDI, the result shows that it is significant in all the models estimated except for the interaction of secondary school education and gross domestic product which is not significant. The validity of instruments underpins the consistency of the GMM estimator, and this is addressed by employing two specification tests; a test of over-identifying restrictions and a test for second-order serial correlation in the error term. The main regressions (GMM) satisfy both the Sargan test of over identifying restrictions and the serial correlation test of both the first and second order.

\section{CONCLUSIONS AND RECOMMENDATIONS}

\section{Conclusion}

This empirical study examines the effect of market size and education on FDI by focusing on the interactive role of market size and education in sub-Saharan African countries. The study focuses on a panel of 30 countries in the region from 2005 to 2015. Market size was proxy by population and gross domestic product. For education, two variables were used as proxy; primary and secondary school enrolment. The result shows that market size and education have positive and significant effect on FDI inflow into the region. The result reveals that market size and education are locational determinant of FDI in the region. The interactive effect of market size and education also reveals a positive and significant effect on foreign direct investment. 


\section{Policy Recommendation}

Based on the above finding, policy maker in the region need to focus more on the quality of education rather than quantity (number of school enrolment), with this, there will be improvement in the quality of labour which can be productively engaged in production of goods and services.

\section{REFERENCES}

Alguacil, M., Cuadros, A., \& Orts, V. (2011). Inward FDI and Growth: The Role of Macroeconomic and Institutional Environment. Journal of Policy Modeling, 33, 481-496.

Alfaro, L., Chanda, A., Kalemli-Ozcan, S., \& Sayek, S. (2004). FDI and Economic Growth: The Role of Local Financial Markets. Journal of International Economics, 64(1), 89-112.

Anyanwu, J. C. \& N. D. Yameogo (2015). Regional Comparison of Foreign Direct Investment to Africa: Empirical Analysis. African Development Review, 27(4), 345-63.

Aziz, A. \& Makkawi, B. (2012). Relationship between Foreign Direct Investment and Country Population. International Journal of Business and Management, 7(8), 63-70.

Bakar, N., Mat, S., \& Harun, M. (2012). The Impact of Infrastructure on Foreign Direct Investment: The Case of Malaysia. Procedia - Social and Behavioral Sciences, 65, 205-211.

Balassa, B. (1966). American Direct Investments in the Common Market. Banca Nazionale del Lavoro. Quarterly Review, 77, 121-146.

Bandera, V. \& White, J. (1968). U.S. Direct Investments and Domestic Markets in Europe. Economia Internazionale, 21, 117-133.

Barro, R. (1991). Economic Growth in a Cross Section of Countries. Quarterly Journal of Economics, 106(2), 407-443.

Beaker S. (1975) Front matter, Human Capital: A Theoretical and Empirical Analysis, with Special Reference to Education, NBER, http://www.nber.org/books/beck75-1

Bond, S. Hoeffler, A. \& Temple, J. (2001). GMM Estimation of Empirical Growth Models, Economics Papers: 2001-W21, Nuffield College, University of Oxford, 1-35

Caballero, R. (2002). Coping with Chile's External Vulnerability: A Financial Problem. Mimeo, MIT.

Chakrabarti, A. (2001). The Determinants of Foreign Direct Investment: Sensitivity Analyses of Cross-Country Regressions. Kyklos, 54(1), 89-114.

Daude, C. \& Stein, E. (2004). The Quality of Institutions and Foreign Direct Investment, mimeo Inter-American Development Bank.

Demirhan, E. \& Masca, M. (2008). Determinants of Foreign Direct Investment Flows to Developing Countries: A Cross-Sectional Analysis. Prague Economics Paper, 4, 356-369.

Desbordes, R. \& Wei, S. (2017). The Effects of Financial Development on Foreign Direct Investment. Journal of Development Economics, 127(1), 153-168.

Dunning, J. H. (1971). The Multinational Enterprise, London, George Allen and Unwin

Dunning, J. H. (1993). Multinational Enterprises and the Global Economy, AddisonWesley Publishing Company 
Glewwe, P., Maiga, E., \& Zheng, H. (2014). The Contribution of Education to Economic Growth: A Review of the Evidence, with Special Attention and an Application to Sub-Saharan Africa. World Development, 59, 379-393.

Goh, S., \& Wong, K. (2010). Malaysia's Outward FDI: The Effects of Host Market Size and Home Government Policy. Monash Business School Department of Economics Discussion Paper No 33/10.

Ho, C., Amir, K., Nasaruddin, L. \& Abidin, N. (2013). Openness, Market Size and Foreign Direct Investments. In: Hooy CW., Ali R., Rhee S.G. (eds) Emerging Markets and Financial Resilience. Palgrave Macmillan, London.

Hoang, H. \& Bui, D. (2015). Determinants of Foreign Direct Investment in ASEAN: A Panel Approach. Management Science Letters, 5(2), 213-222.

Jamison, E., Jamison, D. \& Hanushek, E. (2006). The Effects of Education Quality on Income Growth and Mortality Decline. Economics of Education Review, Elsevier, 26(6), 771-788.

Jaumotte, F. (2004). Foreign Direct Investment and Regional Trade Agreements: The Market Size Effect Revisited. IMF Working Paper.

Kohler, A., (2013). Income Distribution, Market Size, and Foreign Direct Investment, http://www.research-projects.uzh.ch/p18078.htm.

Kravis, I. \& Lipsey, R. (1982). The Location of Overseas Production and Production for Export by U. S. Multinational Firms. Journal of International Economics, 12, 201-222.

Kudaisi, B. (2014). An Empirical Determination of Foreign Direct Investment in West Africa. International Journal of Development and Economic Sustainability, 2(2), 19-36.

Lunn, J. (1980). Determinants of U.S. Direct Investment in the E. E. C.: Further Evidence. European Economic Review, 13, 93-101.

Majeed, M., \& Amed, E. (2008). Human Capital Development and Foreign Direct Investment in Developing Countries, Journal of Economics Corporation, 29(3), 79-104.

Moura, R., \& Forte, R. (2010). The Effects of Foreign Direct Investment on the Host Country Economic Growth - Theory and Empirical Evidence. FEP Working Papers, Research Work in Progress No. 390.

Mughal, M., \& Akram, M. (2009). Does Market Size Affect FDI? The Case of Pakistan. Interdisciplinary Journal of Contemporary Research in Business, 2(9).

Nigh, D. (1985). The Effect of Political Events on United States Direct Foreign Investment: A Pooled Time-series Cross-sectional Analysis. Journal of International Business Studies, 16, 1-17.

Nwosa, P., \& Emma-Ebere, O. (2017). The Impact of Financial Development on Foreign Direct Investment in Nigeria. Journal of Management and Social Sciences, 6(1).

OECD. (2017). FDI flows (indicator). doi: 10.1787/99f6e393-en (Accessed on 26 September 2017).

Petrović-Ranđelović, M., Janković-Milić, V. \& Kostadinović, I. (2017). Market Size as a Determinant of Foreign Direct Investment Inflows in the Western Balkans Countries. Economics and Organizations, 14(2), 93-104.

Sakyi, D., Commodore, R., \& Osei Pokou, E. (2015). Foreign Direct Investment, Trade Openness and Economic Growth in Ghana: An Empirical Investigation. Journal of African Business, 16(1-2). 
Shah, M. H., (2016). The effect of macroeconomic stability on inward FDI in African developing countries. International Journal of Business Studies Review. 1(1), 111.

UNCTAD. (2017) World Investment Report. UNCTAD: Geneva.

Wooldridge J. M. (2001). Applications for Generlaised Method of Moments Estimation. Journal of Economic Perspective, 15(4), 87-100.

Xing, Y., \& Pradhananga, M. (2013). How Important are Exports and Foreign Direct Investment for Economic Growth in the People's Republic of China? ADB Working Paper 427. Tokyo: Asian Development Bank Institute. Available:http://www.adbi.org/working-

paper/2013/07/01/5774.exports.fdi.economic.growth.prc/

\section{Appendix: List of countries}

Angola, Benin, Botswana, Burkina Faso, Burundi, Central Africa Republic, Comoros, Congo Democratic Republic, Congo Republic, Cote d'Ivoire, Gambia, Ghana, Guinea, Kenya, Lesotho, Madagascar, Malawi, Mali, Mauritius, Mozambique, Namibia, Niger, Nigeria, Senegal, Seychelles, South Africa, Swaziland, Togo, Uganda and Zambia. 